\title{
The last days of sugd confederation: the reasons and factors of downturn
}

\author{
Ungalov Azizbek ${ }^{1}$ \\ ${ }^{1}$ Doctorant $(\mathrm{PhD})$ of Samarkand state university \\ Azizbek.ungalov111@mail.ru
}

\begin{abstract}
Relations of the Turkish Khanate with local authorities, the activities of Gurak and Devashtich, the decline of the Sughd Confederation, the military campaigns of Qutayba ibn Muslim, disputes with China, the tax policy of the Arab Caliphate in Movarounnahr, the Muqanna uprising, Said al- Harashi activity

Keywords: Sughd Confederation, Turkish Khanate, Turks, Varkhuman, Ashins, Gurak, Devashtich, Qutayba ibn Muslim, Battle of Talos, Nasr ibn Sayyar, Jizya, Hiraj, Muqanna uprising, Said al- Xaroshi
\end{abstract}

\section{INTRODUCTION}

Sugd which was great cultural oasis of Central Asia is a region experienced important state organization process. Especially, in first medieval ages, state organization reached its peak in Sugd.At that time Sugd was ruled as a confederative state and there were activity of making coin,central city,symbols of state and administrative construction (Ғойибов Б. Суғд конфедерациясида марказий ва махаллий бошқарув тизимихусусида // Илмий хабарнома. Научный вестник. - Андижон, 2015. - №.1 . - Б. 60-65).

The slowdown in the development of the Sogdian confederation, the crises in the economic, political, social and spiritual spheres of the country took place in an interconnected state, and the Sugd confederation fell into decline. The occupation and the process of invasion of Sugd by the Arabs studied by researchers called V.B Henning, V.A Livshits, O.I. Smirnova, B. Gafurov, M. Ishakov, F. Gre-ne, N. Sims-Williams, A. Otahojaev, G.Boboyorov, B.Goyibov, Sh.Shoyokubov and others. However, there are various conflicting views in the scientific literature on the factors that led to the collapse of the Sugd Confederation and the processes that accelerated them. With this in mind, we found it necessary to express our views on the problem (Gayibov B. About Confederative Administration Ruling of Sogd // International Journal of Central Asian Studies. South Korea. Volume 20. 2016. - P. 167-179).

The crisis of the Sugd Confederation was connected with the invasion of Central Asia by the Arab Caliphate, and the first Arab invasions to Movarounnahr took place in the middle of the 7th century.During this period, Ikhshid Varhuman (655) ruled in Sugd (Альбаум Л.И. Живопись Афрасиаба. - Ташкент: Фан, 1975. - C. 28-31).

In 651, the armies of the Arab Caliphate, which had conquered the Sassanid state, captured Marv and began to occupy the lands beyond the Amu Darya (Gayibov B. About to the Question of the Main Origin of Sogdian Rulers // International journal of Humanities \& Social Science Studies. Volume-III, Issue-I. July. Karimganj-Assam, India: 2016. - P. 235-242). They tried to enter the country in two directions, in Poykent and Bukhara, and in the south through Kesh (Пардаев M. IX-X асрларда Жиззах - ғозийлар шахри // Тарих ва қадриятлар. - Тошкент: 2015. - Б. 33-38). It can be seen that almost the same information is given in Chinese chronicles and in the works of Muslim historians (Chavannes E. Documents sur les Tou-kiue (Turcs) occidentaux // Сб. Тр. Орхонской эксп. - СПб.: 1903. - Вып. 6.- Р. 172).

During the period under study, the interests of the Arab Caliphate and the Chinese Empire clashed throughout Central Asia, a process that lasted until the Battle of Talos in 751 (Камалов А.К. Тюрки и иранцы в Танской империи(618 - 907 гг.): Автореф. дисс. ... докт. ист. наук. - Алматы, 2008. - С. 19-20).

During the first Arab military operations in Central Asia, the center of the Sughd confederation moved from Kesh to Samarkand and the kingdoms like Panj,Maymurg,Ishtikhon,Kushoniya,Fay,Kabudon and Kesh were united around the center of confederation Samarkand (Ғойибов Б. Суғд конфедерациясининг шаклланиши, тараққиёти ва таназзули: тарих фанлари бўйича докторлик диссертацияси. - Тошкент: Ўзбекистон миллий университети, 2017. - Б. 206-207).

The Turkish khans could not interfere in the affairs of the confederation due to internal conflicts. Especially during the reign of Ashina Mishe (658-662), such protests intensified and the Khaganate became embroiled in internal strife, and its vassals were unable to interfere in internal affairs. Despite the instability of the internal situation in the khanate, the Sughd confederation remained loyal to the khanate during these years (660-680). Moreover, at a time when the political process was intensifying, it was not in the interests of the Sughd confederation to seek any other refuge. As a result of the frequent change of Western Turkic khagans, Ashina Alp (651-658), Ashina Mishe (658-662), Ashina Burkin (662-666) and Ashina Torchi (671-679) ascended the throne in the 50s and 70s of the 7th century (Смирнова О.И. Очерки из истории Согда. - М.: Наука, 1970 - С. 275; Отахўжаев А. Илк ўрта асрлар Марказий Осиё цивилизациясида турк-суғд муносабатлари. - Тошкент: 2010. - Б. 109). It is not known whether the Turkish khans were involved in the process or not, at a time when the struggle for the Confederate throne reached its peak. The potential of the Western Turkic state has diminished, and control over the political situation has weakened. This was a factor in accelerating the Arab invasion of Central Asia. As a result, various causes and factors led to the crisis of the Sughd confederation In this regard, it is necessary to determine the period of complete confrontation of the Sughd confederation and to study the problem on this basis. In particular, A. Askarov connects the transfer of Volume 3, Issue XI, November 2020|8 
Sughd from the Turks to the Arabs with the events of 737, citing the defeat of the Turks by the Arabs as an evidence (Асқаров А. Ўзбек халқининг келиб чиқиш тарихи. - Тошкент: Ўзбекистон, 2015. - Б. 382). Вut Ghurak and his son Turgar ruled the country in Ishtihan until 750 and with the help of Arabs minted coins (Смирнова О.И. Сводный каталог согдийских монет. Бронза. - М.: Наука, 1981.- С. 191), and in Kesh alIhrid Taran ruled until 760 (Смирнова О.И. Очерки из истории Согда. ... - С. 180, 182). Panch was set on fire by the army of the Arab Caliphate during the suppression of the 720-year uprising (Распопова В. Жилища Пенджикента. - Л.: Наука, 1990. - С. 53, 173). A fire breaks out in the city and houses burn down. The townspeople began to flee, scattered around. By 740, the Sogdians of Panjikent had reached an agreement with Nasr ibn Sayyar (739-748), the vicegerent of the Arab Caliph in Central Asia, and people began to move back to the city, and former city was rebuilt (Большаков О.Г. Отчет о раскопках северо-восточной части объекта III // МИА. - M., 1964. - №124. - C. 119). Only as a result of military operations during the Muqanna Uprising (769 - 783) Panjikent was destroyed and not rebuilt (Ғойибов Б. Суғд конфедерациясида Панчнинг ўрни. Тошкент: Наврўз, 2013. - Б. 78). From this period (late 70s of the VIII century) the rulers of the Sughd confederation are not mentioned in the sources. The processes of the Muqanna uprising were one of the factors that led to the Sughd confederation losing its political existence.

This situation accelerated the decline of the confederation. However, it should be noted that there are a number of other factors that led to the crisis of the Sughd confederation. This is manifested in the following:

First, on the eve of the Arab invasion and during the invasion, the rulers of the Sughd Confederation were hostile to each other. During this period, the struggle against the Arabs intensified during the reign of Gurak and Devashtich, who claimed the throne (Отахўжаев А. Илк ўрта асрларда Марказий Осиё цивилизациясида турк-суғд муносабатлари. ... - Б. 142). In early 719, the rulers of Central Sughd and Bukhara wrote a letter to China asking for military assistance. During this period, the Sogdians revolted against the Arabs, converted from Islam, and revolted again (История ат-Табари / Пер. с арабского В.И.Беляева с допол. О.Г.Большакова, А.Б.Халидова. - Ташкент: Фан, 1987. - С. 175-176). According to Yakubovich, based on the ideas of F. Grene, the army of the Arab Caliphate in Ishtikhan strictly controlled Gurak. He was placed under house arrest and he was unable to take an active part in the proceedings. This helped Devashtich in his struggle for the throne (Якубович И.С. Проблемы согдийской этимологии: диссертация на соис. ученой степени кандидата филологических наук. - М.: 2009. - С. 141). In these turmoil, the rulers of the Sughd kingdoms were in a hostile mood to each other, which was reported through Sogdian documents. In particular, relations between Punch and central Samarkand have become very tense (Ғойибов Б. Суғд конфедерациясининг шаклланиши, тараққиёти ва таназзули: тарих фанлари буйича докторлик диссертацияси. - Тошкент: Ўзбекистон миллий университети, 2017. - Б. 208).

The struggle of the rulers of Sughd for the central throne is one of the main factors that led to the decline of the confederation. The Arabs tried to take advantage of this. Because the assassination of Qutayba ibn Muslim in Fergana in 715 began to weaken the Arab power in Sughd. As a result, the Arabs needed someone to work with them. The riots were perpetrated by the Arabs, who acted under the pretext of sponsoring the sons of Tarhun, who was under the control of Devashtich (Крачковский И.Ю. Древнейший арабский документ из Средней Азии / Избранное сочинения. -М.-Л.: Изд. АН СССР, 1957. - Том. I.- С. 185-186. - С. 53-56). The unrest in the country had a negative effect on the government, which allowed the Arabs to spread their rule. In the spring of 721, Said ibn Abdulaziz (Huzayna) (719-720) was replaced by Said al-Kharoshi (721-723). By this time, the unrest in Sughd had reached its peak, and as a result of relentless military operations, the irrigation system in towns and villages had been disrupted, and there was a famine in the country. This is also stated in the Sughd documents of the Mug Mountain, written at that time. The state was to protect the rights of non-Muslim citizens, protecting them from external and internal aggression (Согдийские документы с горы Муг. Вып. II / Юридические документы и письма / Чтение, перевод и комментарии В.А. Лившица. - М.: ИВЛ, 1962. C. 103). In return, a special tax was levied on them. This tax was mainly a jizya (life tax) levied in cash and in kind, and the Sogdians did not pay the life tax to the Arabs. Al-Kharoshi tries to reach an agreement with the rebels before taking military action against them. According to Balazuri, al-Kharoshi sent envoys against the rebel Sogdians in an attempt to convert them to Islam (Ал-Балазури, Ахмад ибн Йахйа ибн Джабир. Завоевание Хорасана. Извлечения из книги “Китобфутух ал-Булдон” / Перевод извлечений С. Волина в кн. Туркмены. - Ашгабад: 1950. - T.I. - С. 177).

In Arab-occupied administrations, they put into practice the administration they had introduced by abolishing local government or replacing it with local people. When Said al-Kharoshi was appointed deputy, the Sogdians began to leave their homeland. After hearing this, 'Umar ibn Hubayr, the caliph's deputy in Iraq, told them to turn away from this path and to appoint whomever they wished to be their deputy (История ат-Табари. ...- C. 184-185). This was done under the guise of Arabization, and the local confederate system of government was replaced by strict rule. The administration of the Arab Caliphate destroyed the local dynasties and took control (Отахўжаев А. Илк ўрта асрларда Марказий Осиё цивилизациясида турк-суғд муносабатлари. ... Б. $122-123 ; 140-142)$.

Second, the military campaigns of the forces of the Arab Caliphate had a serious negative impact on the socio-economic life of the Sughd Confederation. During this period, the local population and nobility in Sughd began to convert to Islam in order to avoid paying taxes. But in the name of the population's conversion to Islam, they returned to their religion again. Even the rulers embraced Islam for their own ends (Исхоқов М. 
Унутилган подшоликдан хатлар. - Тошкент: Фан, 1992. - Б. 7). As a result, the revenue of the Caliphate will decrease. This required the Khilafah administration to establish or develop new conditions for converts to Islam in Sughd (Гафуров Б.Г. Таджики. Древнейшая, древняя и средневековая история. - Душанбе: Ирфон, 1989. Кн. 2. - C. 22-23). The new conditions would provoke public discontent, and war would break out again in the country. This situation further complicated the situation and led to the complication of the local population. Initially, a jizya tax was levied on non-Muslims, and a xiraj tax was levied on farmers, merchants, and artisans (Кадырова Т. Из истории крестьянских восстаний в Мавераннахре и Хорасане в VIII - начале IX в. - Ташкент: Фан, 1965. - C. 65-67). Later, from the time of Umar II (717 - 720), no jizya tax was levied on the population who converted to Islam. People adopted Islam in the name of Islam and in fact remained in their religion. Circumcision and memorization of Qur'anic verses are now required for conversion to Islam (Отахўжаев А. Илк ўрта асрлар Марказий Осиё цивилизациясида турк-суғд муносабатлари. ... - Б. 123124). It is likely that local deputies in some regions have also introduced some additional conditions for the conversion to Islam in the way of their goals (Ғойибов Б. Суғд конфедерациясининг шаклланиши, тараққиёти ва таназзули: тарих фанлари бўйича докторлик диссертацияси. - Тошкент: Ўзбекистон миллий университети, 2017. - Б. 209);

Third, after the Arab invasion, the Sogdian language was replaced by Arabic and Persian, which became more pronounced in this social life (Исхаков М.М. Преемственность в истории древних тюрских систем письменности (согдийского-тюркские контакты)// O’zbekiston tarixi. - Тошкент, 2000. - №4. - С. 46-57). For the past thousand years, the Sogdian language and script have been the main means of communication in the Central Asian region, despite the fact that Sogdians, Hephthalites, Chachs, Fergana people and Turks lived side by side (Gayibov B. Sogdian Confederation: The Kingdoms Position and Peculiarity // The international journal of Humanities \& Social Studies. Vol. 4. Issue 6. June. - India: 2016. - P. 88-94). Even during the time of the first Turkic khans, the Sogdian language was used in government (Kljaštornyj S.G., Livšic V.A. The Sogdian inscription of Bugut reviced // AOASH. - Budapesht:1972. - Tom XXVI (1). - P. 69-102). But after the Arab conquest, the Sogdian language gradually began to disappear from consumption. But the Sogdian language was not completely lost. Muqaddas left the following information about the Sogdian language: "In Sogd (Zarafshan oasis) there is a unique language, which is similar to the language of the people of Bukhara." This indicates that at that time Persian was used only in cities (Зухра Заршинос. Суғд тилига умумий бир нигох / СИНО илмий-адабий, фалсафий-ирфоний, маънавий-маърифий журнал. 2010. 37-38-39-40 сонлари. - Б. 7). Тhе number of people who speak Arabic and Persian is higher than the Sogdian language. This process showed that the Sughd confederation was losing its existence not only politically or economically, but also socially and culturally (Ғойибов Б. Суғд конфедерациясининг шаклланиши, тараққиёти ва таназзули: тарих фанлари бўйича докторлик диссертацияси. - Тошкент: Ўзбекистон миллий университети, 2017. - Б. 210).

Fourth, another factor that accelerated the decline of the confederation was related to this religion. It is known that on the eve of the Arab invasion in Sughd there were such religious views as Zoroastrianism, Buddhism, Christianity, Monism (Ставиский Б.Я., Большаков О.Г., МончадскаяЕ.А. Пянджикентский некрополь //МИА. - М., 1953. - № 37. - С. 67-89; Беленицкий А.М. Раскопки согдийских храмов в 19481950 гг. // МИА. - М., 1953. - №37. - С. 23; Беленицкий А.М. Вопросы идеологий и культов Согда (по материалам пянджикентских храмов) // Живописьдревнего Пенджикента. - М.: 1954. - С. 39-52, 62-81). People from different religions have different assessments of the current situation, which has served as a basis for Islam to emerge as a stable religion and to unite people around a single idea (Бартольд В.В. Арабское завоевание и Туркестан при Саманидах / Соч. - М.: Наука, 1963. - Т. II (1). - С. 142; Бартольд В.В. К истории арабских завоеваний в Средней Азии / Соч. - М.: Наука, 1964. - Т.II (2). - С. 380-388).

Fifth, the administration of the Arab Caliphate, which sought to establish its dominance over Sughd, took the path of collusion with the upper classes here. For example, the part of the Sogdians who were fighting against the Arabs under the leadership of Korzanch had to make an agreement with the king of Fergana Alutar (700 - 720) and pass through Khojand to Fergana. However, Alutar betrayed Korzanch, handed him and his men over to the Arabs, and the Sogdians, tired of the relentless battles, fought against the Arabs to the last breath. This is how the Sogdians and Korzanch's military actions ended tragically. Only 400 wealthy households were able to buy their blood from the Arabs. While the local rich initially paid money (Смирнова О.И. Очерки из истории Согда. ... - С. 256-258.) and bought their liberties to reconcile with the Arabs, later the Arabs themselves needed people who had a place in society. Such people supported the Arab rulers even in the disputes over the throne. The later Tahiriy state (821-873) was also established under the auspices of the Arab Caliphate (Бу хақда батафсил қаранг: Ибн ал-Асир. Ал Камил фи-т-тарих (“Польный свод истории”). Избранные отрывки / Перевод с арабского языка, примечания и комментарии П.Г. Булгакова. Дополнения к переводу, примечаниям и комментариям, введение и указатели Ш.С. Камалиддина. Ташкент-Цюрих: 2005. - С. 20-31; Бартольд В.В. Туркестан в эпоху монгольского нашествия / Соч. - М.: ИВЛ, 1963. - Том I. - С. 265-267).

Based on the above considerations, the following conclusions can be made:

- One of the reasons for the forgetting of the Sogdian language is the policy of "Arabization", as a result of which protests over language, culture, religion and ethnicity have caused many conflicts. Arabic has been sanctified by rising to the level of the state language. Those who knew him could read the Qur'an and pray. As a result, local culture was largely destroyed. In particular, the fine arts were severely damaged during the Arab 
invasion;

- The Turkish Khanate as a result of the marches of the Arab Caliphate and the territories under the control of the Sogdian confederation were lost. Caliphate domination was established. The spread of Islam gained momentum. In customs the transformation process intensifies. Ethnic and social significance of Sogdiana also began to disappear. The Sogdians entered with the Turkish population and the Arab army Western Iran, which had arrived, began to mix with the Persian-speaking contingent. As a result, the ground was laid for the formation of the modern Tajik and Uzbek peoples on a new basis. However, it cannot be said that the Sogdian script and the culture created during this period have completely disappeared. The Sogdian script served to strengthen the friendship between the peoples, diplomatic ties, and to provide us with a lot of information about the formation of a common alliance against the enemy's invasion.

Thus, the decline of the Sughd Confederation was due to the march of the forces of the Arab Caliphate. The decline of the Sogdian confederation was a dynamic transition period in the history of Uzbekistan, during which the population of the cities of the confederation experienced various social processes associated with the transition from Sogdian to Uzbek and Tajik ethnicity. At a time when the religion and culture of Islam were entering the world in various ways and methods, there was a different historical destiny in Movaroun-Nahr, which, in the old language, had a strong political disintegration, was divided into small states, and the power of the Turkish Khanate was broken by the Chinese. it was difficult.

\section{References}

1. Ал-Балазури, Ахмад ибн Йахйа ибн Джабир. Завоевание Хорасана. Извлечения из книги "Китобфутух ал-Булдон" / Перевод извлечений С. Волина в кн. Туркмены. - Ашгабад: 1950. - T.I. - C. 177.

2. Ибн ал-Асир. Ал Камил фи-т-тарих (“Польный свод истории”). Избранные отрывки / Перевод с арабского языка, примечания и комментарии П.Г. Булгакова. Дополнения к переводу, примечаниям и комментариям, введение и указатели Ш.С. Камалиддина. Ташкент-Цюрих: 2005. - С. 20-31;

3. История ат-Табари / Пер. с араб. В.И. Беляева с допол. О.Г. Большакова, А.Б. Халидова. Ташкент: Фан, 1987. - С. 175-176

4. Крачковский И.Ю. Древнейший арабский документ из Средней Азии / Избранное сочинения. -М.-Л.: Изд. АН СССР, 1957. - Том. І.- С. 185-186. - С. 53-56.

5. Смирнова О.И. Сводный каталог согдийских монет. Бронза. - М.: Наука, 1981.- С. 191.

6. Согдийские документы с горы Муг. Вып. II / Юридические документы и письма / Чтение, перевод и комментарии В.А. Лившица. - М.: ИВЛ, 1962. - С. 103.

7. Chavannes E. Documents sur les Tou-kiue (Turcs) occidentaux // Сб. Тр. Орхонскойэксп. - СПб.: 1903. - Вып. 6.- Р. 229.

\section{Scientific literature and collections}

1. Альбаум Л.И. Живопись Афрасиаба. - Ташкент: Фан, 1975. - С. 28-31.

2. Асқаров А. Ўзбек халқининг келиб чиқиш тарихи. - Тошкент: Ўзбекистон, 2015. - Б. 382.

3. Бартольд В.В. Туркестан в эпоху монгольского нашествия / Соч. - М.: ИВЛ, 1963. - Том I. - C. 265-267.

4. Бартольд В.В. Арабское завоевание и Туркестан при Саманидах / Соч. - М.: Наука, 1963. T. II (1). - C. 142.

5. Бартольд В.В. К истории арабских завоеваний в Средней Азии / Соч. - М.: Наука, 1964. T.II (2). - C. 380-388.

6. Беленицкий А.М. Раскопки согдийских храмов в 1948-1950 гг. // МИА. - М., 1953. - №37. C. 23

7. Беленицкий А.М. Вопросы идеологий и культов Согда (по материалам пянджикентских храмов) // Живописьдревнего Пенджикента. - М.: 1954. - С. 39-52, 62-81.

8. Большаков О.Г. Отчет о раскопках северо-восточной части объекта III // МИА. - М., 1964. №124. - С. 119.

9. Гафуров Б.Г. Таджики. Древнейшая, древняя и средневековая история. - Душанбе: Ирфон, 1989. Кн. 2. - С. 22-23.

10. Исхоқов М. Унутилган подшоликдан хатлар. - Тошкент: Фан, 1992. - Б. 7.

11. Кадырова Т. Из истории крестьянских восстаний в Мавераннахре и Хорасане в VIII начале IX в. - Ташкент: Фан, 1965. - С. 65-67.

12. Отахўжаев А. Илк ўрта асрлар Марказий Осиё цивилизациясида турк-суғд муносабатлари. - Тошкент: 2010. - Б. 109.

13. Пардаев М. IX-X асрларда Жиззах - ғозийлар шахри // Тарих ва қадриятлар. - Тошкент: 2015. - Б. 33-38.

14. Распопова В. Жилища Пенджикента. - Л.: Наука, 1990. - С. 53, 173.

15. Смирнова О.И. Очерки из истории Согда. - М.: Наука, 1970 - С. 275. 
16. Ставиский Б.Я., Большаков О.Г., МончадскаяЕ.А. Пянджикентский некрополь //МИА. М., 1953. - № 37. - С. 67-89

17. Ғойибов Б. Суғд конфедерациясида Панчнинг ўрни. - Тошкент: Наврўз, 2013. - Б. 78.

18. Kljaštornyj S.G., Livšic V.A. The Sogdian inscription of Bugut reviced // AOASH. Budapesht:1972. - Tom XXVI (1). - P. 69-102.

\section{Author's abstracts and dissertations}

1. Камалов А.К. Тюрки и иранцы в Танской империи(618 - 907 гг.): Автореф. дисс. ... докт. ист. наук. - Алматы, 2008. - С. 19-20.

2. Якубович И.С. Проблемы согдийской этимологии: диссертация на соис. ученой степени кандидата филологических наук. - М.: 2009. - С. 141.

3. Ғойибов Б. Суғд конфедерациясининг шаклланиши, тараққиёти ва таназзули:тарих фанлари бўйича докторлик диссертацияси. - Тошкент: Ўзбекистон миллий университети, 2017.

\section{Scientific journals}

5. Зухра Заршинос. Суғд тилига умумий бир нигох / СИНО илмий-адабий, фалсафийирфоний, маънавий-маърифий журнал. 2010. 37-38-39-40 сонлари. - Б. 7.

6. Исхаков М.М. Преемственность в истории древних тюрских систем письменности (согдийского-тюркские контакты)// O’zbekiston tarixi. - Тошкент, 2000. - №4. - C. 46-57.

7. Ғойибов Б. Суғд конфедерациясида марказий ва махаллий бошқарув тизимихусусида // Илмий хабарнома. Научный вестник. - Андижон, 2015. - №.1. - Б. 60-65.

8. Gayibov B. Sogdian Confederation: The Kingdoms Position and Peculiarity // The international journal of Humanities \& Social Studies. Vol. 4. Issue 6. June. - India: 2016. - P. 88-94.

9. Gayibov B. About Confederative Administration Ruling of Sogd // International Journal of Central Asian Studies. South Korea. Volume 20. 2016. - P. 167-179.

10. Gayibov B. About to the Question of the Main Origin of Sogdian Rulers // International journal of Humanities \& Social Science Studies. Volume-III, Issue-I. July. - Karimganj-Assam, India: 2016. 